have recently begun to lay are most susceptible, but hens and cockerels are sometimes affected.

The disease is characterized by a sudden drop, sometimes almost a complete cessation, of egg production, accompanied by marked cyanosis of comb and wattles, dullness, loss of appetite, watery diarrhoea. Many birds in the flock (up to $90 \%$ ) may be affected but mortality is usually low (about $2-20 \%$ ). Recovery generally takes place in about 14 days, but it is often about a month before egg production returns to normal.

Post-mortem examination shows the carcass to be fevered. The crop is often partly impacted with grass and the contents are sour-smelling. The most striking lesion is nephritis, usually accompanied by visceral gout. The ovules are misshapen as a result of absorption and the yolk appears to be thinnish in consistency and sometimes has a greenish tinge. Frequently an ovule ruptures, allowing yolk to escape into the abdominal cavity.

Treatment is empirical. Food is withheld for $12 \mathrm{hr}$. and Epsom salts are given in the mash or in the drinking water. This is said to give satisfactory results in the early stages. Potassium salts have also been tried, with variable results.

In conclusion I should like to stress what should have been obvious from this paper, namely, the importance of an adequate and complete diet for breeding stock, thus ensuring under normal conditions of incubation and brooding the hatching and rearing of healthy, vigorous chicks well equipped to withstand the rigours of post-embryonic life. A deficiency of any essential constituent, whether vitamin or mineral, in the food of the adult may result in poor fertility and give rise to a high embryonic mortality and weakly chicks, handicapped in life from the outset.

\title{
REFERENCES
}

Greenwood, A. W. \& Blyth, J. S. S. (1948). World's Poult. Congr. virt. Copenhagen, p. 687.

Kull, K.-E. (1948). World's Poult. Congr. virl. Copenhagen, p. 124.

Temperton, H. \& Bythell, D. W. P. (1944). Vet. Rec. 56, 409.

\section{Some Peculiarities of Avian Metabolism}

\section{By W. Bolton, Poultry Research Centre, King's Buildings, West Mains Road, Edinburgh, 9}

In this paper on avian nutrition I propose to deal with peculiarities in nitrogen and calcium metabolism. These can both be traced back to the oviparous mode of reproduction in the fowl and, before they are considered in detail, the radical differences between oviparous and viviparous animals should be discussed.

First of all, the avian embryo develops inside a hard box, the cleidoic egg, whose shell is composed largely of calcium carbonate; the mammalian embryo develops in the uterus. The shell is necessary to provide protection for the developing embryo, but as it is fairly impervious to water it also helps to keep down evaporation losses from the 
egg. The avian egg contains not only the food supply of the embryo but also the water supply. This is severely limited, and this constitutes the second great difference between avian and mammalian embryos, as the mammalian embryo has the whole of the maternal water supply at its disposal for the elimination of waste products.

The effects of the restricted water supply of the avian embryo are clearly seen in the nitrogen metabolism.

\section{Metabolism of nitrogen}

There are three main ways in which animals excrete waste nitrogen: as ammonia, urea or uric acid. Ammonia is toxic at low concentrations, whereas urea and uric acid are relatively innocuous, and among terrestrial animals, whose water supply is not so unlimited as that of aquatic animals, urea and uric acid predominate. Urea, however, is very soluble in water, and if the avian embryo excreted its waste nitrogen as urea the newly hatched bird would, by human standards, be in a very uraemic condition. Uric acid, on the other hand, is almost insoluble and can be deposited inside the shell in solid form.

Needham (1926) has made an intensive study of the nitrogen metabolism of the chick embryo. He found that all three methods of elimination (as ammonia, urea or uric acid) were exhibited by it. The excretion of nitrogen as ammonia reached a peak at the

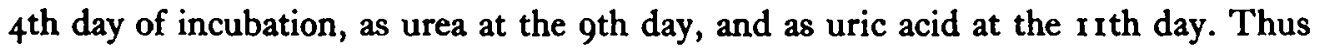
nitrogen is excreted in the simplest form first, and in its most complicated form last. This is in keeping with the morphology of the developing embryo, for the gill-slits disappear after the $5^{\text {th }}$ day. When the results obtained are expressed as percentages of the total nitrogen excreted over the whole incubation period, it is found that uric acid accounts for $9 \mathrm{I} \cdot 5$, urea for 7.6 and ammonia for only $1 \%$. This demonstrates that, so far as the chick is concerned, uric acid is by far the most important end-product of nitrogen metabolism.

It has been found (Kamei, 1928) that during the development of the embryo the uric acid concentration in it remains at a low level, while the concentrations of urea and ammonia rise considerably; the concentrations of urea and ammonia are rapidly reduced after hatching, indicating that the increased concentration in the embryo is purely a temporary expedient to tide it over a period of acute water shortage.

Two further points are worthy of notice. Fiske \& Boyden (1926) found that $15 \%$ of the water in the egg was used in excreting the $5 \mathrm{mg}$. uric acid present in the allantois at the I Ith day of incubation, but that from then onwards reabsorption of water from the allantois proceeded vigorously. Common (1936) found that heavy phosphorus excretion at the time of egg laying may also involve heavy ammonia excretion, and suggested that this phosphorus is excreted as ammonium phosphate in the urine, the fowl thereby effecting an economy in bases.

In the mammal, Krebs \& Henseleit (1932) have postulated the existence of a urea cycle. In this cycle arginine is split into urea and ornithine, the ornithine combines with ammonia to form citrulline, and the citrulline combines with more ammonia to re-form arginine. 'The change from arginine to ornithine and urea is effected by the enzyme arginase, which is found abundantly in mammalian liver, and, indeed, in the 
livers of all ureotelic animals (Clementi, 1915). But arginase is absent from the avian liver, though present in the kidney (Clementi, 1915), and hence the change from arginine to ornithine cannot take place in the liver. Moreover, whereas citrulline can replace arginine in avian nutrition, ornithine is without effect (Klose \& Almquist, 1940), indicating that yet another enzyme necessary for the Krebs cycle is absent.

It is therefore improbable that the Krebs-Henseleit urea cycle can take place in the fowl. This is consistent with the evidence (Needham, Brachet \& Brown, 1935; Lazzaro, 1937) that urea is not a precursor of uric acid for the fowl, or for the pigeon.

The main difference in nitrogen metabolism between the fowl and the pigeon is that whereas the liver of the fowl can form uric acid from ammonium salts (Needham et al. 1935), the liver of the pigeon is unable to do so (Edson, Krebs \& Model, 1936). If, however, a mixture of pigeon liver and kidney is used uric acid is formed. A further difference is found in the xanthine oxidase contents of the two birds; fowl liver contains this enzyme but pigeon liver does not, although it is found in the kidney of the pigeon. Ormström, Ormström \& Krebs (1939) showed that when ammonia was taken up by pigeon liver a purine accumulated, and they identified this purine as hypoxanthine. Hypoxanthine, which can be formed from alanine and a source of carbon (Reindel \& Schuler, 1937), is presumably transported to the kidney and there dehydrogenated to uric acid (Schuler \& Reindel, 1935).

It is, therefore, doubtful whether arginine enters into the metabolism of uric acid. However, arginine plays an important part in avian metabolism, for arginase occurs in the kidney of the fowl, and in the embryo an arginine-arginase system is established at about the 2nd day of incubation (Needham et al. 1935), thereby accounting for the limited excretion of urea by both embryo and adult. Moreover, although the rat can synthesize arginine, the fowl is unable to do so and loses weight on a diet low in this amino-acid (Klose, Stokstad \& Almquist, 1938).

One of the components of the urea cycle, ornithine, is used by the fowl to detoxicate benzoic acid, whereas mammals use glycine. This may be due to a difficulty in mobilizing glycine since, though the chick has a limited power to synthesize glycine (Patton \& Palmer, 1936), it is unable to do so in amounts sufficient to meet the metabolic demands for rapid growth (Almquist, Stokstad, Mecchi \& Manning, 1940; Almquist \& Mecchi, 1940, 1942), and glycine must be classed as an essential amino-acid for the fowl, although it is not essential for the rat.

A deficiency of glycine leads to a weakness resembling paralysis, low muscle-creatine content, poor growth and poor feather formation (Jukes, 194I $a$ ). This syndrome can be prevented by the administration of creatine (Almquist \& Mecchi, 1940; Jukes, 194 I $a, b$ ), which indicates that glycine is a precursor of creatine for the chick as well as for the rat.

Another factor in chick nutrition, the cartilage factor, may now be considered. Hegsted, Oleson, Elvehjem \& Hart (1939) observed that the feeding of cartilage increased the growth rate of chicks, and later Hegsted, Hier, Elvehjem \& Hart (I94I) found that glycine and chondroitin or a pentose were involved in this factor.

Meanwhile, Almquist, Mecchi, Stokstad \& Manning (1940) and Almquist, Stokstad, Mecchi \& Manning (1940) had been investigating a growth factor present in polished rice, and also found that chondroitin possessed growth-promoting properties, but could 
be replaced by glucuronic acid. Stokstad, Almquist, Mecchi, Manning \& Rogers (r94I) found that chondroitin could be replaced by arabinose, xylose, ribose, rhamnose or gum arabic. The value of the first two of these has been confirmed by Hegsted, Briggs, Elvehjem \& Hart (194I), and of the last by Jukes (194xa,b).

Further work (Briggs, Mills, Elvehjem \& Hart, 1942) has shown that the cartilage growth-factor consists of glycine, arginine, chondroitin or some other source of pentose sugar, and either cystine or methionine.

Though the metabolism of the pentose sugar has not been worked out, Calvery $(1928 a, b)$ has shown that a pentosenucleic acid, similar to those in plants, is present in chick tissues in addition to the more usual hexosenucleic acids.

It will be seen from the above remarks that the metabolism of nitrogen compounds in the fowl differs in many respects from that in the mammal, the most important being the essential nature of glycine and arginine for the fowl and the absence of the KrebsHenseleit urea cycle.

The actual method by which uric acid is formed has not yet been established and, indeed, our knowledge on this point is somewhat meagre. We know that uric acid can be formed from ammonia, or from alanine; that hypoxanthine, and by presumption xanthine, are involved as intermediaries, but further than that we cannot go. The problem of the formation of uric acid is now being investigated by the use of isotopic forms of carbon and nitrogen (Sonne, Buchanan \& Delluva, 1948a,b). By thus labelling the individual atoms taking part in the biochemical reactions it should be possible at least to map out the general reactions taking place, although it must be borne in mind that unstable intermediary products cannot be isolated for analysis.

The associated problem of the mode of transport of uric acid is also under investigation (Levine, Wolfson \& Lenel, I947). Using birds with ligatured ureters to increase the uric acid concentration, these workers found that only a small portion of the uric acid was transported as true urate in the plasma; a larger amount was transported in combination with protein, and over $70 \%$ was present in the plasma as colloidal urate.

\section{Metabolism of calcium}

It was mentioned above that the phenomenon of the cleidoic egg also leads to another important difference between the fowl and the mammal. In order to reduce evaporation losses to a minimum, and to provide a degree of security and safety for the developing embryo, the egg substance is encased in a hard shell, composed largely of calcium carbonate. It is only to be expected, therefore, that the calcium metabolism of the fowl will differ markedly from that of the mammal.

At the onset of laying, a pullet's body contains about 25-30 g. calcium. Each egg produced represents a draft of about $2 \mathrm{~g}$. calcium. When a bird is laying heavily she may lay an egg every day for several weeks; for example, a bird at the Poultry Research Centre laid ninety-seven eggs on consecutive days; this represented a draft of $194 \mathrm{~g}$. calcium, and the total draft of calcium in a laying season may easily amount to $500 \mathrm{~g}$., or about twenty times the initial body content.

It is obvious that this calcium must have been supplied by the diet, and a consider- 
able amount of work has been done on the comparative values of different sources of calcium and on the quantitative requirement of calcium and phosphorus for optimum egg production. Halnan (1925), working on weekly balance data, showed that the net demands for laying are almost completely covered by an increased retention from food during laying periods, and also drew attention to an increased retention of calcium and phosphorus in the week preceding the onset of laying.

The next step was to break down the weekly balances into daily balances (Common, 1932). This work showed that calcium retention begins to increase a week or so before laying commences, i.e. just about the same time as the ova begin that final rapid growth which culminates in ovulation. This suggested that both processes were controlled by endocrine activity, and, further, that the most obvious place to look for the extra calcium was the skeleton.

Attention was then focused on the pigeon, whose regular ovulation cycle has been so valuable in work on avian reproduction. This cycle (Riddle \& Reinhart, 1926) consists in a pre-ovulation period of $108 \mathrm{hr}$., ovulation of the first egg, an inter-ovulation period of $44 \mathrm{hr}$., ovulation of the second egg, and a post-ovulation period of $108 \mathrm{hr}$.

Kyes \& Potter (1934) examined a large number of pigeons at different stages of this cycle and observed that the pre-ovulation period was characterized by an intense ossification of the spongy bony tissue and bone marrow of the long bones. The new bone was broken down rapidly during shell formation, re-formed again in the interovulatory period, again broken down rapidly while the shell of the second egg was forming, and finally reverted to the normal resting condition during the post-ovulation period.

It has been shown recently (Common, Rutledge \& Hale, 1948; Common, Bolton \& Rutledge, 1948) that a similar effect can be produced in the fowl by injecting oestrogen and androgen into the immature fowl. Oestrogen alone evokes hypertrophy of the oviduct and changes in blood calcium and phosphorus similar to those encountered in the laying fowl, but only in conjunction with androgen was the reddening of the comb and wattles observed, and an increased retention of calcium and phosphorus. Though thyroxine depressed the high levels of calcium and phosphorus in the blood, it did not decrease the high rate of calcium retention.

However, 15 years ago skeletal material had a greater reputation for stability than it enjoys to-day, and the next evidence came from a consideration of the excretion of phosphorus on a low-calcium diet (Common, 1932). It became evident on plotting the phosphorus excretion that this was sharply discontinuous. During the $24 \mathrm{hr}$. before laying (i.e. the period of shell formation) the phosphorus excreted rose, and the lower the calcium intake, the higher was the phosphorus excretion, but if soft-shelled eggs were laid on diets of low calcium content the phosphorus excretion did not increase.

The possible presence of labile calcium in the skeleton was investigated by Common (1938) by combining daily balance data with carcass analyses. He demonstrated that the hen could utilize up to one-quarter of its body calcium for shell production before laying was prejudiced. More recently Morgan, Mitchell, Ringrose \& Lease (1942) confirmed this work, and showed that as much as one-third of the body calcium may on occasion be rapidly mobilized in this way. Burmeister, Scott \& Card (1939) found that 
shell secretion took place at a rate of I $3 \mathrm{mg}$. calcium/hr., and Morgan \& Mitchell (1938) found an average rate of retention of $76 \mathrm{mg}$. calcium/hr. with diets containing almost $4 \%$ calcium, indicating that even with such high dietary levels there must be a drain on skeletal calcium during shell formation. Common (1943) found that the fowl can withdraw skeletal calcium at a rate of $66 \mathrm{mg}$. $/ \mathrm{hr}$., which is more than sufficient to cover the difference between the observed rates of retention and excretion.

Tyler (1940) introduced two assumptions which enabled him to simplify greatly the calculation of his results. These were: (I) that in short-term balance experiments any appreciable changes in phosphorus and calcium balance can be related almost exclusively to skeletal changes; (2) that bone is a mixture of calcium orthophosphate $\left(\mathrm{Ca}_{3} \mathrm{PO}_{4}\right)_{2}$ with non-phosphatic or residual calcium. He was then able to show that laying pullets receiving daily $2 \mathrm{~g}$. calcium in their food as carbonate retained calcium at a steady rate of I g./day. Therefore, on days of shell secretion, I g. calcium came from the food and I g. must have come from the skeleton. Since phosphorus excretion was almost constant, this extra I g. calcium must have come from the non-phosphatic or residual calcium of the skeleton. Therefore, so long as the calcium supplied in the diet is non-phosphatic, the formation of residual calcium occurs on non-laying days, and its breakdown on laying days. There also appears to be a slight tendency for calcium retention to be higher on days of shell formation than on days when no shell is formed.

Lastly, there is now evidence to suggest that calcium retention is less effective in the earlier weeks of laying by pullets, leading to cumulative negative balance, which is restored later in the laying season (Morgan et al. 1942).

The phenomenon of the secretion of the egg-shell may now be considered. The immediate stimulus is mechanical; this was shown by Tarchanoff (1884) 65 years ago by dropping amber balls into the active oviduct, and it has since been confirmed by Pearl and others (cf. Conrad \& Scott, 1938).

There is evidence that carbonic anhydrase activity may be involved (Common, 194 $\mathrm{r} a$ ), and sulphanilamide administration has been shown (Benesch, Barron \& Mawson, 1944) to lead to the laying of soft-shelled eggs, presumably by the inhibition of carbonic anhydrase, but the story of why and how the orderly shift of calcium metabolism towards new internal ossification of the bones is suddenly reversed when the egg reaches the shell gland remains to be unravelled.

We have, however, a fair idea of how calcium is carried in the blood. The actual transport is effected under the stimulus of endocrine secretions, and most of these changes in the blood can be evoked by hormone injections in immature pullets (McDonald \& Riddle, 1945; Common \& Bolton, 1946; Common, Rutledge \& Bolton, 1947; Common, Rutledge \& Hale, I948).

These changes include large increases in serum calcium which do not, however, greatly affect the concentration of the calcium ion. There is evidence to suggest that most of this extra calcium is transported in combination with serum proteins, especially the serum vitellin, and to some extent as colloidal calcium phosphate (McDonald \& Riddle, 1945). It is noteworthy that the mode of transport of calcium is similar to that found for uric acid in azotaemic fowls. There is also evidence to suggest that the alkali reserve is normally increased (Common, $194 \mathrm{I} b$ ). A suggestion that calcium citrate may 
be involved (Dickens, I94I) was not supported by work on immature pullets in which gonadal hormones were used to simulate the other chemical and anatomical changes occurring during egg laying (Common, Bolton \& Rutledge, 1948).

Blood analysis, however, can only reveal the traffic on the road, it cannot give any indication of the conditions at the points of despatch and delivery, and it is to these that we must next turn our attention. It has already been mentioned that isotopic forms of carbon and nitrogen are being used in investigations into the mode of formation of uric acid, and work has been commenced with isotopic phosphorus in the problems of calcium and phosphorus metabolism (O'Neil, Jowsey, Lee, Meade \& Spinks, 1948).

The synthesis of uric acid and the metabolism of calcium are, however, complicated problems, and though we have made a certain amount of progress in their solution, much remains to be accomplished.

\section{REFERENCES}

Almquist, H. J. \& Mecchi, E. (1940). F. biol. Chem. 135, 355.

Almquist, H. J. \& Mecchi, E. (1942). Proc. Soc. exp. Biol., N. Y., 49, 541.

Almquist, H. J., Mecchi, E., Stokstad, E. L. R. \& Manning, P. D. V. (1940). F. biol. Chem. 134, 465. Almquist, H. J., Stokstad, E. L. R., Mecchi, E. \& Manning, P. D. V. (1940). F. biol. Chem. 134, 213. Benesch, R., Barron, N. S. \& Mawson, C. A. (1944). Nature, Lond., 153, 138.

Briggs, G. M. Jr., Mills, R. C., Elvehjem, C. A. \& Hart, E. B. (1942). Ұ. biol. Chem. I44, 47.

Burmeister, B. R., Scott, H. M. \& Card, L. E. (1934). World's Poult. Congr. vil. Cleveland, Ohio, p. 99.

Calvery, H. O. (1928a). F. biol. Chem. 77, 489 .

Calvery, H. O. (1928b). F. biol. Chem. 77, 497 .

Clementi, A. (1915). Arch. Fisiol. 13, 189.

Common, R. H. (1932). F. agric. Sci. 22, 576.

Common, R. H. (1936). F. agric. Sci. 26, 85 .

Common, R. H. (1938). F. agric. Sci. 28, 347.

Common, R. H. (1941 a). F. agric. Sci. 31, 412.

Common, R. H. (1941 b). Y. agric. Sci. 31, 281 .

Common, R. H. (r943). F. agric. Sci. 33, 2 r3.

Common, R. H. \& Bolton, W. (1946). Nature, Lond, 158, 95.

Common, R. H., Bolton, W. \& Rutledge, W. A (1948). F. Endocrinol. 5, 263.

Common, R. H., Rutledge, W. A. \& Bolton. W. (1947). F. Endacrinol. 5, 121.

Common, R. H., Rutledge, W. A. \& Hale, R. W. (1948). F. agric. Sci. 38, 64 .

Conrad, R. M. \& Scott, H. M. (1938). Physiol. Rev. 18, 481.

Dickens, F. (194I). Biochem. F. 35, I0II.

Edson, N. L., Krebs, H. A. \& Model, A. (1936). Biochem. F. 30, 1380.

Fiske, C. H. \& Boyden, E. A. (1926). F. biol. Chem. 70, 535.

Halnan, E. T. (1925). J. nat. Poultr. Inst. 10, 410.

Hegsted, D. M., Briggs, G. M., Elvehjem, C. A. \& Hart, E. B. (1941). F. biol. Chem. I40, I 91.

Hegsted, D. M., Hier, S. W., Elvehjem, C. A. \& Hart, E. B. (1941). F. biol. Chem. r39, 863.

Hegsted, D. M., Oleson, J. J., Elvehjem, C. A. \& Hart, E. B. (1939). F. biol. Chem. 130, 423.

Jukes, T. H. (1941 a). F. Nutrit. 22, 315.

Jukes, T. H. (1941 b). Proc. Soc. exp. Biol., N.Y., 46, I 55.

Kamei, T. (1928). Hoppe-Seyl. Z. I71, ror.

Klose, A. A. \& Almquist, H. J. (1940). F. biol. Chem. r35, I 53.

Klose, A. A., Stokstad, E. L. R. \& Almquist, H. J. (1938). Y. biol. Chem. 123, 691.

Krebs, H. A. \& Henseleit, K. (1932). Hoppe-Seyl. Z. 210, 33.

Kyes, P. \& Potter, T. S. (r934). Anat. Rec. 60, 377.

Lazzaro, G. (1937). Arch. Fisiol. 37, 515.

Levine, R., Wolfson, W. Q. \& Lenel, R. (1947). Amer. F. Physiol. r51, 186.

McDonald, M. R. \& Riddle, O. (1945). F. biol. Chem. 159, 445.

Morgan, C. L. \& Mitchell, J. H. (1938). Poult. Sci. 17, 99.

Morgan, C. L., Mitchell, J. H., Ringrose, R. C. \& Lease, E. J. (1942). Poult. Sci. $21,212$.

Needham, J. (1926). Brit. F. exp. Biol. 4, 45.

Needham, J., Brachet, J. \& Brown, R. K. (1935). F. exp. Biol. 12, 32 I.

O'Neil, J. B., Jowsey, J. R., Lee, C. C., Meade, M. A. \& Spinks, J. W. T. (1948). Science, $107,295$. Ormström, A., Ormström, M. \& Krebs, H. A. (1939). Biochem. F. 33, 990. 
Patton, A. R. \& Palmer, L. S. (1936). F. Nutrit. 11, 129.

Reindel, W. \& Schuler, W. (1937). Hoppe-Seyl. Z. 247, 172.

Riddle, O. \& Reinhart, W. H. (1926). Amer. F. Physiol. 76, 660.

Schuler, W. \& Reindel, W. (1935). Hoppe-Seyl. Z. 234, 63.

Sonne, J. C., Buchanan, J. M. \& Delluva, A. M. (1948a). Y. biol. Chem. 173, 69.

Sonne, J. C., Buchanan, J. M. \& Delluva, A. M. (1948b). F. biol. Chem. 173, 8r.

Stokstad, E. L. R., Almquist, H. J., Mecchi, E., Manning, P. D. V. \& Rogers, R. E. (194r). F. biol. Chem. 137,373 .

Tarchanoff, J. R. (1884). Pflüg. Arch. ges. Physiol. 33, 303.

Tyler, C. (1940). Biochem. F. 34, 202.

\section{Practical Aspects of Poultry Feeding}

\section{By T. E. Whitrle, Poultry School for Scotland, West of Scotland Agricultural College, Auchincruive, Ayr}

Before the war poultry in Britain were fed on mixtures composed largely of imported cereal products. Highly concentrated foods like maize and wheat were used in large quantities and a high efficiency of utilization was obtained. Cost of feeding was relatively very low, owing to the abundance and cheapness of imported cereals. For instance, in 1939, immediately before the war, it was possible to buy large quantities of Canadian wheat at $£_{5} /$ ton delivered on the farm. The price to-day is about $£_{25} /$ ton for non-millable wheat.

During the last to years both cereal and protein feeds have been very scarce, and the feeding of poultry, in common with that of pigs, has been dominated entirely by the effects of rationing. As both poultry and pigs compete strongly with human beings for cereal foods, severe rationing had to be applied, although in point of fact poultry are the most efficient of all farm animals in converting digestible protein (into eggs and meat), whereas pigs are the most efficient converters of energy or carbohydrate.

\section{Effects of rationing}

The system of rationing of poultry is based on the number of birds on the holding before the war, i.e. the 'basic' figure, and at the worst period in 1942 established commercial poultry keepers were rationed officially to one-eighth of the basic number, with an acreage deduction of four birds for every 3 acres as an additional restriction. Even to-day official rations to commercial producers are restricted to one-fifth of the pre-war basic figure, although in Britain the number of birds kept is almost as great as before the war, and in Scotland last year's returns exceeded nine million birds, the highest ever recorded. The rationing of pigs is on similar lines, although the numbers kept are little more than half those of pre-war. The main effects of rationing may be summarized as follows.

\section{Unrationed supplements}

Unrationed supplements are extensively used in an effort to feed more birds, often a sheer necessity in order to make a living. These foods are of two main types:

(a) Bulky watery foods, e.g. potatoes, carrots, house-scraps, and processed (steamed and evaporated) house-scraps from heavily populated areas, i.e. industrial 'pudding'. 